DOI: 10.22559/folklor.849

folklor/edebiyat, cilt:25, sayı:98, 2019/2

\title{
Ölü Bedenin Sınırlanan Mekânı: Kayseri'deki Çerkes Kimlikli Mezarlar
}

\author{
Limited Place of the Dead Body: Graves with Circassian \\ Identity in Kayseri
}

\section{Zeynep Kantemur ${ }^{1}$}

\section{Öz}

Bir topluluğun kimliğinin köklerine uzanmak, belki de ancak yaşayanların ve ölülerin mekânlarını açığa çıkarmakla mümkün olabilir. Dolayısıyla topluluğun kendi kimliğini tanımlama şekilleri, mekân ile kurmuş olduğu ilişkilerde görünür bir hâl alır. Mekân ve kimlik ilişkisi bağlamında ölüm ve onun etrafında oluşan ritüellerin de kimliğin dışavurumu yönünden çeşitli ipuçları barındırdığı varsayılabilir. Bu açıdan bakıldığında, geçiş dönemlerinden biri olan ölümün ritüel mekânı mezarlıklar ve mezarlar, kültürel kimliğin inşa sürecinde rol oynar. Bu sebeple bu makalede, kendilerini Çerkes olarak tanımlayan ve Kayseri'de yaşayan kişilerin, ölümün mekânı mezar ve mezarlıklarda görünür kıldıkları kimlik inşa biçimlerine yer verilmiştir. Kayseri ve Sivas arasında uzanan Uzunyayla'da çok sayıda Çerkes köyü yer aldığından, burası Türkiye'de Çerkeslerin yoğun nüfusla yerleştiği alanlardan biri olarak kabul edilir. Ayrıca Uzunyayla bölgesi, coğrafi özellikleri açısından Kafkasya ile benzerlikler taşımamasına karşın, Kayseri'de yaşayan Çerkesler tarafından Çerkes geleneklerinin korunması ve yaşatılması gibi nedenlerden dolayı "Küçük Kafkasya" olarak adlandırılmaktadır. Bu makalenin amacı ise mekân ve kimlik ilişkisi bağlamında, kendilerini Çerkes olarak tanımlayan ve Kayseri'de yaşayan kişilerin, ölü bedeni ve yeri (mezar) üzerinden topluluk kimliğini yaşatmadaki rolünü ortaya çıkarmaktır.

Erciyes Üniversitesi, Sosyal Bilimler Enstitüsü, Kültürel Çalışmalar Anabilim dalı Yüksek Lisans mezunu. zeynepkantemur38@gmail.com 
Makale, 2016 yılının temmuz ayı ile 2018 yılının aralık ayı arasında yapılan bir alan çalışması 1şı̆̆ında oluşturulmuştur. Bu alan araştırması, Kayseri şehir merkezinde yaşayan Çerkesler ile yapılmıştır. Nitel araştırma yöntemi kullanılarak yapılan bu çalışmada, katılarak gözlemin yanı sıra yarı yapılandırılmış görüşmeler de gerçekleştirilmiştir. Araştırmada, Kayseri'de yaşayan Çerkeslerin, Çerkes kimliklerini sürdürmek için gündelik stratejilerin yanında ölüm pratiklerine ve ölüm uzamlarına da yer verdikleri ortaya çıkmıştır. Gündelik yaşamlarındaki gibi mezarlarında da aile damgalarını ve Adigey Cumhuriyeti'nin bayrak figürlerini de kullanmaktadırlar.

Anahtar sözcükler: Çerkes, mezarlık, ölüm, mekân, kimlik

\begin{abstract}
Tracing to the roots of a community identity can be possible only by uncovering the places of the living and the dead. Therefore, the manners of defining the identity of their own community emerge in its dependence within the place. In the context of place and identity dependence, it can be assumed that the death and its rituals can give traces in terms of expressions of identity. In this point of view, cemeteries as ritual spaces for death, one of the rites de passage, have a function in the construction process of the cultural identity. Since there are many Circassian villages in Uzunyayla extended along in Kayseri and Sivas, it is considered as one of the regions in Turkey where Circassians are densely populated. Moreover, although the geographical features of the region are not similar to Caucasia, Uzunyayla is named as "Little Caucasia" by its people because of preserving and sustaining the Circassian traditions. Thus, this article includes the identity constructions of the people who identify themselves as Circassian and live in Kayseri through the dead bodies and graves as the ritual spaces for death. The aim of this article is to reveal the role of dead body and its place (grave) in keeping the community identity alive in the context of place and identity relations. The data of this study collected in a fieldwork conducted in between July 2016 and December 2018. This fieldwork was carried out with Circassians living in the city centre. Qualitative research method was used in this study, and semi structured interviews were conducted along with participant observation. The research reveals that Circassians in Kayseri city centre feature death practices and deathscapes in addition to their daily life for sustaining their Circassian identity. They also use their family signets and flag symbols of the Adyghe Republic in their graves and in their daily life as well.
\end{abstract}

Keywords: Circassian, grave, death, place, identity

\title{
Giriş
}

Ölüm, beden ile ruhu birbirinden ayırdığı gibi mekânlar arasında çizilen sınırları da belirginleştirir. Yaşayan beden nasıl bir kimlik ve mekân ölçeğinde varlığını sürdürüyorsa, ölü beden de kendine has yeni ve eski kimliklerle mekân içinde konumlandırılmış aynı zamanda da sınırlandırılmıştır. Ölüm ile birlikte bedensel ve ruhsal geçişini gerçekleştiren insan, kendisi için düzenlenen ritüeller vasıtasıyla mekânın yapısını ve ruhunu da değiştirir. Sıradan bir ev, ölüm ile birlikte ölü evi veya cenaze evi gibi geçici tanımlamalar ile bir nevi kutsallaştırılmakta ve gündelik olma özelliğinden sıyrılarak ritüel mekân kimliğine büründürülmektedir. 
Kayseri kent merkezindeki Çerkeslere odaklanan bu makale, ritüel bir mekân olan kent mezarlıklarının kimliğin inşa sürecinde ne gibi rolleri olduğunu ele almaktadır. Bu rolleri anlamak için Kayseri kent merkezindeki Çerkeslerle nitel bir alan araştırması yapılmıştır. ${ }^{1}$ Konuyu derinlemesine anlamak için topluluk üyelerinden yirmi beş kişi ile 07.07.2016 ile 10.07.2017 tarihleri arasında aralıklı olarak görüşmeler gerçekleştirilmiştir.

Kümbetoğlu'nun ifadesiyle nitel araştırma, "sosyal olanın bilgisinin insanların kendi ifade ve anlatılarından derlendiği” bir yöntemdir (2005, s.38). Bu özelliği ile nitel araştırma, kişi veya toplulukların olayları kendi değerlendirme süreçlerinden geçirerek oluşturdukları tabloya odaklanır. Nitel araştırma yöntemi içerisinde, derinlemesine görüşmelerin yanı sıra araştırmacının içeriden olma durumu nedeniyle etnografiyle daha çok anılan katılarak gözlem tekniğine de başvurulmuştur. ${ }^{2}$ Katılarak gözlemin, dışarıdan gözleme oranla daha çok bilgi verdiğini belirten Karasar için dışarıdan gözlem de davranışların nedenleri gözlem yapan kişi tarafından anlaşılmaya çalışılır; fakat katılarak gözlem vasıtasıyla bu nedenler daha derin ve geçerli bir temele dayandırılarak sunulabilir (1995, s.158). Nahya ve Harmanşah'ın ifade ettiği gibi “katılarak gözlemde araştırmacı, topluluğun bulunduğu yerde veya mekânda daima bulunmaya çaba gösterir; sosyal etkinliklere olabildiğince katılır; sürekli gözlem yapma halinin yanı sıra sohbetlerle alan bilgisini elde eder” (2016, s.22). Bu açıdan bakıldığında katılarak gözlem yöntemi ile mekânı yaşayanların kimliği üretme biçimleri ve mekânsal hareketlerinin nedeni, nasılı ve niçini gibi sorulara daha ayrıntılı cevapların verilmesi mümkün olmaktadır.

\section{Bir kökene dayanmak: Çerkes olmak}

Çerkes sözcüğünün kökeni hakkında birçok farklı görüş yer alır. Çerkes sözcüğü, bazı araştırmacılar tarafından Antik Yunanca bir sözcük olan ve Kuzeybatı Karadeniz kıyısında yaşayan halkları tanımlamak için kullanılan "Kerket” sözcügünün günümüze değin değişerek gelmiş hali olarak tanımlanır (Avagyan, 2004, s.10). Saltık’a göre Kuzey Kafkasya'da yaşayan ilk yerli halklar olan Sind, Meot, Dizıh vd. bugünkü Adigelerin atalarıdır (2000, s. 17). Bağ’ın yaptığı tanıma göre ise Çerkes adlandırması, Karadeniz'den Hazar Denizi'ne kadar bütün Kuzey Kafkasya halklarını kapsayacak şekilde genişletilmiştir.

Çarlık Rusyası tarafından 1858-1864 yılları arasında gerçekleştirilen zorunlu göç sonucunda Kuzey Kafkasya'da varlık sürdüren ve aralarında Çerkeslerin de bulunduğu farklı boy ve kabileler dünyanın çeşitli yerlerine gönderilmişlerdir. Sayıları hakkında kesin bir bilgiye ulaşmak mümkün olmamasına rağmen yurtlarını terk etmek zorunda kalan nüfusun yaklaşık 1 ila 1.5 milyon kişi aralığında olduğu sanılmaktadır (Avagyan, 2004, s.60). Ürdün, Suriye, İsrail gibi ülkelerin yanında Türkiye'ye de gönderilen Çerkesler, Osmanlı iskân politikası çerçevesinde ülkenin değişik şehirlerine yerleştirilmişlerdir. Samsun, Tokat, Maraş, Adana, Çanakkale ve Balıkesir bölgeleri ile İç Anadolu'da Kayseri, Sivas ve Tokat şehirleri yoğun Çerkes nüfusuna sahip alanlar olarak kayda geçirilmiştir (Saltık, 2000, s.45-46).

Kayseri sınırları içerisindeki Uzunyayla bölgesi, Çerkeslerin yoğun olarak nüfuslandığı yerleşim alanlarından biridir. Bu bölgede birçok Çerkes köyü yer alır. Ayrıca Kayseri'de yaşayan Çerkesler bölgeyi coğrafi özellikleri açısından benzer olmasa da geleneklerin korunması ve yaşatılması açısından el değmemiş olması gibi özellikleri nedeniyle "Küçük Kafkasya" olarak nitelendirmektedirler. Kentte ise Çerkesler daha çok merkezden uzak olan izole 
alanlar olarak tanımlanabilecek ve nispeten Uzunyayla bölgesine ulaşım olanakları kolay olan semtleri tercih etmektedirler. Bu semtler arasında araştırmanın gerçekleştirildiği İldem, Kayabaşı, Beyazşehir ve Mimsin sayılabilir. Bu semtlerin sokaklarını arşınlarken Çerkes kimliğinin belirteci olan bir takım ögelere rastlamak mümkündür.

Savaş sonucunda ana vatanlarından ayrılarak başka ülkelere göç etmiş ve kentin kozmopolit potası içerisinde erimek istemeyen diaspora, kişisel kimliğinin yanında, kolektif bir Çerkes kimliğini de beraberinde getirmiştir. Yapılan görüşmelerde edinilen bilgiler ışı̆̆ında Kayseri'de yaşayan Çerkesler kendilerini ortak kader inancı bağlamında "sürgün toplumu" olarak tanımlamakta ve genetik benzerlikleri referans göstererek "diğer topluluklardan farklı olduklarını”, Çerkesliğin onlar için “gurur verici bir deneyim” olduğunu aktarmışlardır (Kankush, 2017 ve Gonuque, 2017).

‘21 Mayıs Sürgünü, ile Kafkasya’dan Kayseri’ye gelip yerleşmiş atalarımız. Ben bu sürgünü tanımlarken şöyle bir cümle kuruyorum hep, denizin karnı mezarı olan ataların torunlarıyız biz. O dönemde atalarımızın mezarları bile yok, cesetleri Karadeniz'de kaybolmuş. Bizim sülale buraya gelirken Kafkasya'daki Lape Nehri’ni geçemeyen yaşlı bir kadın varmış, onu bir ineğin sırtına bindirip nehri geçmesini sağlamışlar ve daha sonra Samsun, dolaylarından Türkiye'ye giriş yapmışız ve Osmanlı Devleti de bizi sınır boylarına ve Kayseri'de Uzunyayla bölgesine yerleştirmiş. Oraya ilk yerleşen atalarımız evlerini yaparken sadece dört tarafı kapalı duvarlar örmüşler çünkü tamamen yerleşim yeri olarak benimsememişler, Kafkasya'ya dönme fikrini zihinlerinde tutuyorlarmış. Fakat bu mümkün olmamış, dönmeye çalışanlar da Çarlık Rusyası tarafından yok edilmiş" (Yevtıgh, 2016).

Yukarıdaki aktarımda hem Çerkes kimliğinin temel bileşenleri olan sürgün, anavatan Kafkasya, göç yolları gibi bir takım özelliklere rastlanılmakta hem de sürgün ile birlikte kaybolan ataların mezarlarının durumuna vurgu yapılmaktadır. Mezarlıkların denizin dibi olması ve mezar taşlarının dahi olmaması toplumsal bellekte yer edinmiş ve kültürel olarak yok olma tehlikesi ile karşı karşıya kalındığı gerçeği ile dönüş fikrinin zihinlerde canlı tutulduğu gözler önüne serilmiştir.

Ayrıca ev sahibi ülkedeki yeni yerleşim yeri kent içerisindeki homojenleştirme hareketlerine karşın, diaspora toplulukları veya azınlıklar, kendi farklılıklarını vurgulayacak, onları ayırt edilir kılacak yeni taktiksel eğilimler içerisine girebilirler. Bu bağlamda Boz, diasporanın maruz kaldığı, "ev sahibi ülkenin entegrasyon politikaları”, "toplumdaki ayrışmalar” ve "yabancı düşmanlığının" "etnik mekânlar" adı verilebilecek yerleşimlerin oluşmassına ortam hazırladığını ifade eder (2009, s.310). Bu açıdan bakıldığında giderek büyüyen kent yaşamının yok ediciliğine karşın kültürel kolektivizmin kurtuluş olduğunu savunan diasporalar, kendi yaşam alanlarını inşa etmeye meyilli olabilirler. Bunu yaparken de birtakım birleştirici unsurları, yaşamış oldukları kültürel travmaları, gelenek, görenek, örf, âdet gibi yerellikleri dayanak göstererek kamusal alanda olmasa da, kendi özel yaşam alanlarında kolektif bir kimlik üretmeye çabalayabilirler.

Makaleye temel oluşturan araştırma, Çerkeslerin yoğun nüfuslandığı yerlerden Kayseri kentinin kamusal alanlarından biri olan mezarlıklarda gerçekleştirilmiş ve mezar taşları üzerindeki sembollerden yola çıkılarak Çerkes kimlikli mezarlar incelenmiştir. Ayrıca Çerkeslerin düzenlemiş oldukları cenaze törenlerine katılarak orada gözlemler ve görüşmeler yapılmıştır. ${ }^{3}$ 


\section{Mekân(d)a dokunan kimlikler}

Ait olma duygusu, insanın varoluşundan beri temel ihtiyaçlarından birisidir. Her insan kendini bir mekâna, toplumsal statüye ya da etnik gruba ait "hisseder." Gündelik hayattaki aidiyetlerimizin bütünü ise toplumsal kimliğimizin oluşum sürecinde önemli rol oynar. "Kimsin?" ya da "Kendini nasıl tanımlıyorsun?" gibi sorulara verilen cevaplar, kişilerin kendi kimliklerini üretim süreçlerinde hangi aidiyet biçimini ön plana çıkardıklarını gösterir. Kişilerin kimliklerini inşa ederken kullanmış oldukları aidiyet ve tanımlama biçimlerinin bir yönü de mekânsaldır. Yaşanılan coğrafyanın ekolojik yapısı, kişilerin ya da toplumların kimliklerinin oluşumunda etkilidir. Kimi zaman sulak arazilere yerleşmiş olan topluluklar tarımcı kimlikleriyle ön plana çıkarken, kimi zaman da diğer bölgelerde yerleşik durumda bulunanlar hayvancılık, sanayi, teknoloji, ekonomi gibi diğer faaliyet alanlarına ait kimlikleriyle üretim biçimleri üzerinden tanınmaktadırlar. Yine aynı şekilde kimi insan toplulukları, yaşadıkları bölgelere göre "Dağlı”, "Doğulu”, "Batılı”, "Şehirli”, "Köylü” gibi değişik toplumsal kimliklendirilme süreçlerine dâhil olabilmektedirler. Dolayısıyla insan mekân(d)a dokunan kimlikleriyle topluluk içerisindeki konumunu edinir. Bu konum kimi zaman kişiselliğe kimi zaman da kolektifliğe vurgu yapar.

Mekânın oluşumuna katkı sağlayan herşey mekânın içerisinde yer alır ve onun kimlik edinme sürecinde aktif rol oynar. Mekânı kelimelerle adlandırmamızı ve ona kimlik atfetmemizi sağlayan şey, orada bulunan nesneler, işaretler, semboller canlı ve cansız varlıklardır. Yani özneler ve nesneler mekânda birlikte yer alırlar.

Mekândaki özne insandır ve bu insan, üretmiş olduğu nesnelerle ya da kendini tanımlama biçiminde kullanmış olduğu kelimelerle mekâna aidiyetini gösterir. Toplumsal mekân, toplum tarafından şekillendirilir. Lefebvre'nin de dediği gibi “insan sadece kelimelerle yaşamaz; her "özne" kendini tanıdığı ya da yitirdiği, dolayısıyla yararlandığı ya da değiștirdiği bir mekânın içine yerleşir" (2014, s.64). Bu çerçevede o "toplumsal mekân formunu, buluşma bir araya gelme ve kendiliğindenlik" olarak tanımlamaktadır. Bir araya gelen şeyler nedir diye sorulduğunda verdiği yanıt, "mekân içinde olan her şeydir" yani "doğa veya toplum tarafından ya da bunların işbirliğiyle olduğu kadar çatışmalarıyla da üretilen; canlı varlıklar, şeyler, eserler, nesneler, işaretler ve semboller"dir (Lefebvre, 2014, s.125).

Bir toplumun mekânsal pratiğini anlamak ise, mekânın deşifre edilmesiyle mümkündür. Mekânı deşifre etmek bir anlamda onun alışıldık görüntüsünün altında yatan simgesel anlamları ortaya çıkarmaktır denilebilir. Toplum üyeleri tarafından sıkça ziyaret edilen mekânlar, kolektif bir düşüncenin varlığına işaret eder. Kimi mekânlar toplumun her kesimine hitap ederken, diğerleri sadece belli bir kesimin ilgisini çeker. Yani mekânı algılama ve anlamlandırmadaki bu türden farklılıklar ortak tarih, kültür ve hatıraların var olup olmadığıyla yani kolektif bellek ile ilgilidir. Assmann'ın belirttiği gibi bellek kendisini mekânla birlikte üretir. Kültürel bellek, grubun kendisini [yeniden] tanımlamasını ve aidiyetine olan güveninin arttırılmasına katkıda bulunur Ona göre "diasporadaki halk, mekânı yeniden yaratmayı deneyerek, sembolik anlamda [da] kendisini [yeniden] üretmektedir” (1997, s.47).

İnsanın mekânda yaşadığı deneyim aslında Stavrides'in deyimiyle "beden ilişskileri deneyimidir” (2016, s.135). İnsanlar çoğu zaman bedensel olarak bir mekâna yerleşme kaygısı gütmüşlerdir. Bu düşünceyi Ponty’nin “mekân bedenimin olduğu her yerdir” ifadesi ile açıklamak mümkündür. $\mathrm{O}$, mekânın beden olmadan da varlığını sürdürebilme olanağı varken, insan bede- 
ninin mekânsız yaşayamayacağını ileri sürer. Bedensel olarak kendini bir mekânda rahat hisseden insan, orayı alışkanlıklarının uygulanabilirliği açısından değerlendirmiş, bunun sonucunda da mekâna olan duygusal ve fiziksel bağını güçlendirmiştir. Böylece mekâna aidiyet, içerisinde kök salma yani "mekâna beden vasitasıyla tutunma" edimini barındırır (2012, s.298-299). Dolayısıyla belirli bir alana kök salan insan, orayı kendi yaşam alanına dönüştürür. Kartarı ise; mekâna sahip olma duygusunun sadece kişisel değil, gruba özgü niteliklerinin de olduğuna değinir. Gruplar, ürettikleri mekânlarla birlikte toplumun geri kalanı ile aralarına sınırlar çizerek onlardan soyutlanma yolunu seçebilirler (2006, s.172-173). Bu açıdan bakıldığında etnik grupların neden kendi özel mekânlara ihtiyaç duydukları anlam kazanır. Etnik gruba ait olan kişi, grubun kültürel mekânında kendisini daha rahat ifade etme özgürlüğüne kavuşabilir.

Savage vd.'ne göre aidiyet ne varoluşa ne de söyleme dayalı olarak görülmelidir. İnsan hareketlerindeki geçici istikrarsızlıklara rağmen yerleşim yeri nispeten sabit kalır. "Çalkantılı ve bol hareketli dünya yaşamında" yerleşim yeri olarak mekân, insanlara evinde hissetme duygusunu tattırmaya devam etmektedir (vurgu benim, 2005, s.12). Evde ya da yuvada olmak güvenlik, özgürlük ve korunma içgüdüsünü uyandıran bir durumdur. Bachelard'ın belirttiği gibi yeni doğan bir bebek için tehlikelere karşı beşiği nasıl bir koruma kalkanı oluşturuyorsa, ev ya da yuva denilen "insanlarla dolu olduğunda anlam kazanan” mekânlar da yetişkinlerin beşikleridir (1996, s.55). Kimi zaman mekânla kurulan bağlar öylesine güçlüdür ki yaşarken bedeninin doğup büyüdüğü yerleri sürekli deneyimlemesini isteyen kimi insan toplulukları, ruhu bedeninden ayrıldıktan sonra da o topraklara gömülerek adeta mekâna karışmak ister. Temel ihtiyaçların karşılandığı gündelik mekânlar haricinde geçiş dönemlerini kolaylaştırmak amaciyla kültürel olarak inşa edilen ritüel mekânlardan da söz etmek mümkündür.

\section{Ritüel mekânlarda kimlik inşası}

Durkheim için ritüeller dinsel törenlerdir. Bu dinsel törenler sadece bireylerin belleklerini canlı tutmakla kalmayıp, ortak bilincin oluşmasına da olanak tanırlar. Topluluk ile gerçekleştirilen ritüeller kişilere güç ve güven duygusunu aş1lamaya yarar. Ritüeller esnasında kolektif bilinç, kişisel bilincin üzerinde iktidar kurar ( 2010, s.513-514).

Assmann içinse ritüeller bir grubun kimlik sisteminin alt yapısını oluşturmaktadır. Ritüeller topluluk kimliğinin oluşması ve yeniden üretimi aşamasında etkili olan toplumsal edimlerdir (1997, s.152). Öyle ki birlik ve bütünlük duygularını perçinlemesi açısından ritüelin gerçekleştirildiği mekân, topluluk kimliğine bürünüp, gündelik işlevinden farklı bir amaç için de kullanılabilmektedir.

Marshall ritüellerin "uygun zamanda yerine getirilen ve sembollerin de kullanılabildiği ve sık sık tekrarlanan bir davranış modeli” olduklarını ifade etmektedir. Ona göre ritüellerin etkili olduğu başlıca alanlardan biri din olmasına rağmen, gündelik hayatta da gerçekleştirilen davranışlar ritüel olma özelliği gösterebilir (2003, s.623). Bu anlamıyla ritüeller geniş bir perspektiften ele alınması gereken toplumsal edimler olarak karşımıza çıkar.

Ritüelleri aşamalarına göre inceleyen Turner, eşikte olma halinden bahseder. Eşikte olan kişilerin "gelenek, görenek ve yasalar ile dayatılan" muğlak konumda olduklarını ifade eder. Ona göre her kabile toplumu bu geçişleri yaşamaktadır (2013, s.177-178). Bu açıdan ba- 
kıldığında ritüeller bu eşikte olma halinden kişiyi kurtarmak amacıyla düzenlenen kolektif edimlerdir. Örnek de geçiş dönemlerinde uygulanan adet, gelenek ve göreneklerin ait olduğu coğrafya, mekân, alan veya bölgenin özelliklerinden etkilendiğini ifade eder (1977, s.131). Görüldüğü gibi ritüeller her toplumun kendine has kimlik özellikleri tarafından biçimlendirilmiş kolektif bilincin ürünleridir.

Ritüellerin gerçekleştirildiği açık, yarı-açık veya kapalı mekânlara toplu bir adlandırma olarak ritüel mekân denilebilir. Özel bir ritüel mekânı olabileceği gibi, gündelik bir mekân, topluluğun kutsal kabul ettiği günlerde ve zamanlarda dönüşerek ritüel mekân atmosferine de kavuşabilir. Örneğin sıradan bir ev, ölüm ile birlikte ölü evi, dügün ritüeli ile birlikte dügüun evi, kız evi veya erkek evi gibi tanımlamalarla kutsallaştırılmakta ve mekân gündelik olma özelliğinden sıyrılarak ritüel mekân kimliğine büründürülmektedir. Bu makalede ele alınan ritüel mekân ise ölü beden vasıtasıyla kültürel bir kimlik inşasına olanak tanıyan mezarlıklardır.

\section{Bir aidiyet mekânı olarak mezarlıklar}

Lefebvre'nin bahsettiği gibi insanlar üretmiş oldukları mekânlarda doğar, büyür, gelişir ve ölürler (2014,s.65). Nasıl ki anne karnı, onların toplumsal bir ürün olarak inşasına olanak tanıyan bir yerse, mezarlıklar da onlar tarafından inşa edilen bir mekândır. Ritüel mekân olarak nitelendirebileceğimiz mezarlıklar, "soy bağını yaşatması ve atalar kültünü yansıtması" bakımından topluluklar için kültürel bir bellek alanıdır. Kültürel bellek söz konusu olduğunda özellikle "ölülerin hatırlanması bağlamında ölüm etrafında oluşan görsel alan" önemlidir. Mezarlıklarda geçmişten bugüne toplulukların kültürel belleğinin izinin sürülebileceği gibi pek çok toplulukta ortaya çıkan ölüm sonrası tören veya anmaların da gerçekleştiği gözlemlenmektedir (Sağır, 2013, s.130). Ölümün mekânında sergilenen davranış kalıpları ve toplumsal pratikler kültürden kültüre farklılıklar arz edebilir. Bu açıdan mezarlıklar aynı zamanda kent içerisindeki kültürel mozaiğin göstergesi olarak hali hazırda işlev görürler.

Mezar taşları toplulukların tamamladıkları yaşam döngüsündeki kimlik ve mekân ilişkisine de gönderme yapar. Zira Akçar ve Ülker de mezarlıkları ve mezar taşlarını yerleşim yerinin kimlik kartlarına benzetirler. Topluluğun geçirmiş olduğu kimlik değişimini, tarihini ve bugünkü kimliğini göstermesi bakımından mezarlıklar, incelenmesi gereken ritüel mekânlardandır (2014, s.505). Sağır'ın da makalesinde vurguladığı gibi mekân ve kimlik arasında mezarlıklar aracılığıyla görselleşen ilişki, mezarlıkların aynı zamanda kültürel bellek oluşumuna gönderme yapmaktadır. Mezarlıklar, çoğu zaman "ölümün soğukluğundan korunma amacıyla yapılan etkinlikler alanı” kimi zamansa toplumsal belleğin kendisini bulduğu alan olması özelliği ile toplumsal kimliklere yansımaktadır (2013,s.131).

Ölen kişi, bedensel olarak aktif bir konumda bulunmamakta, fakat mezarlık üzerindeki soyuna ait amblemler, manevi olarak toplumsal bütünleşmeye katkı sağlamaktadır. Mezar taşları ise adeta ölen kişiyle bağlantı kurma aracı olarak işlev görmektedir. Bu taşlar, ölen kişinin yattığı mekânın sınırlarının belirlenmesinde yol göstericidir. Yaşayan her insan nasıl ki bir mekâna yerleşiyor ve orayı kendi zevk ve tercihlerine göre inşa ediyorsa, ölen kişi de henüz yaşarken, öldükten sonra yatacağı mekânı kendisi belirleyebilir ve kendi isteği doğrultusunda dış görüntüsünü inşa edebilir veyahut ailesi onun için bu sınırlamayı yapar. 
Mezar taşları evlerin kapı zili üzerindeki isimleri andırır. Kim ziyaret edilmek isteniyorsa gidilir ve mezar taşında yazan ismin önünde durulur. Kendileri uzakta olsa da mezar taşı vasıtasıyla imgesine bakılan kişilerin ziyaretine gelen tanıdıklarını hissettikleri düşünülür. Mezarda yatan ölünün de ziyaretçisini gördüğü, duyduğu farz edilir. Hatta kimi zaman gündelik hayattaki gelişmelerden bahsedilir. Mezar taşına veya toprağa sarılarak okşanır, ağlanır. Tüm bu davranış biçimleri, mezar taşlarının ve toprağın kişileştirildiğini, ölen kişinin kimliğine büründürüldüğünü düşündürür.

Ölümün kültürel bellek ile kimlik arasında kurduğu ilişki biçimi büyük şehirlerde aile mezarlıklarının oluşmasına kaynaklık etmektedir. Kayseri'de yaşayan Çerkeslerde de aile mezarlığı geleneği bulunmaktadır. İldem Gesi bölgesinde yer alan mezarlıklarda ölen kişinin ait olduğu sülalesi ya da boyunun isminin yer aldığı mezar taşlarına sıkça rastlanılmaktadır. Bu mezar taşlarında orada yatan kişinin kim olduğu, hangi boya mensup olduğu, hangi köyden olduğu, doğum ve ölüm tarihi gibi bilgilere yer verilmektedir.

Assmann'ın Kültürel Bellek adlı eserinde değindiği üzere soy ağaçları, formatif metinler kategorisine girmekte ve topluluğun biz kimiz sorusuna cevap vermektedir. Bu açıdan bakıldığında da toplumsal belleğin tanımlanmasında ve "kimlikle ilgili kesin kanaat" oluşmasına yardımcı olmaktadırlar (1997, s.151). Çerkes toplumunda her ailenin ve sülalenin kendisine özgü bir damgası ya da arması bulunmaktadır. Bu arma ve damgalar, geçmiş dönemlerde hayvancılıkla uğraşan Çerkeslerin kendi hayvanlarını, başkasınınkilerle karıştırmamak amacıyla kullandıkları birer sembol olarak işlev görmekteydi. Görüşmecilerden edinilen bilgiye göre her Çerkes evinde, ailenin armasının yer aldığı adına Wubce denilen duvar süslerinin bulunduğu belirtilmiştir. Wubceler genellikle keçenin üzerine aile damgalarının süslü bir şekilde işlenmesi ile oluşur ve isteğe göre değişik renklerde yapılır, dekoratif amaçlı olarak kullanıldığı söylenir (Bjedug 1, Bjedug 2, Kankush 1, 2017).

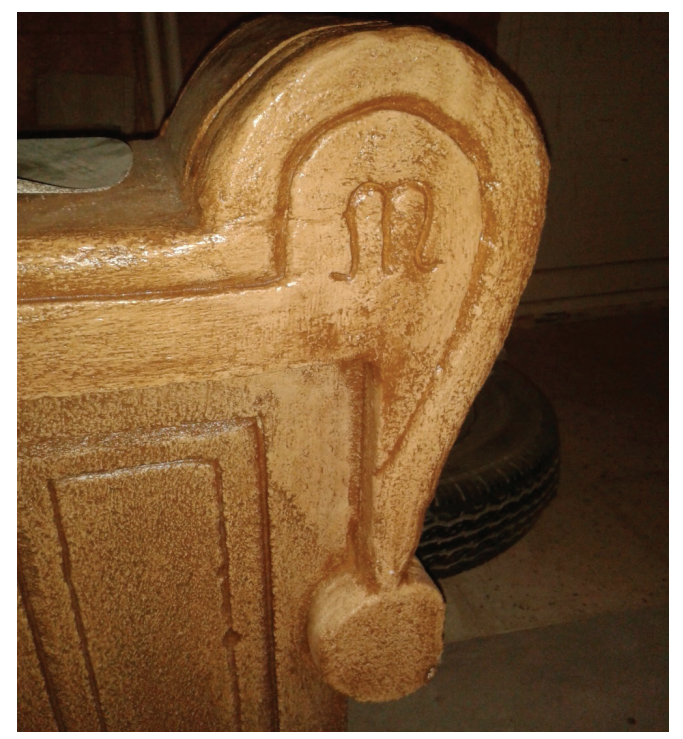

Fotoğraf 1. Bir evde merdiven başına yapılmış Wubce örneği, 19.11.2017, Kayabaşı Mahallesi) 
Durkheim damga düşüncesinin toplumsal birliğin maddi göstergesi olarak ortaya çıktığ1$\mathrm{n}$ ı ifade eder. Yanı sıra toplumsal bütünleşmenin sağlanabilmesi için simgelerin kullanılması gerektiğini de aktarır. Ona göre bir oymağı ya da kabileyi bir arada tutan şey, kullanmış oldukları damga ve sembollerdir (2010, s.318-322). Kozmopolit özellikleri olan kent merkezinde günümüz Kayseri Çerkesleri de kimliklerinin devamlılığını sağlamak ve kültürel belleğin birikim haznesini geliştirmek, gelecek kuşaklara kimlik aktarımını sağlamak gibi amaçlarla mezar taşlarının üzerinde kendi aile damgalarını kullanmayı tercih etmektedirler.

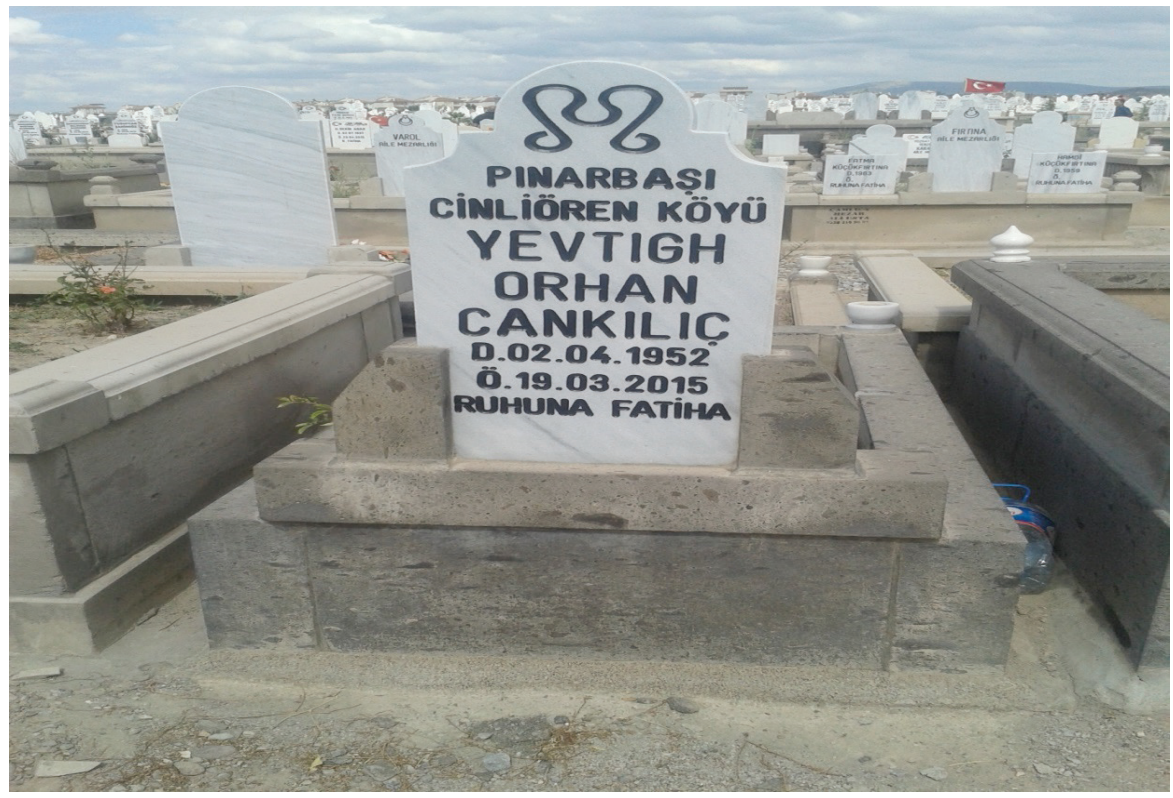

Fotoğraf 2. Mezar taşı üzerine yapılan sülale Tamğesı, İldem mahalle mezarlığı (01.03.2016)

Kimi mezar taşlarında ise çoklu toplumsal kimliklere aidiyeti gösteren birtakım semboller yer almaktadır. Çoklu toplumsal kimlikler literatürde "hibrit kimlik" kavramı ile tanımlanır. Çağırkan hibrit kimliğin oluşumunda en önemli faktörün göç olduğunu ileri sürer (2016, s.2621). Örneğin mezar taşlarına, Türk bayrağında yer alan ay ve yıldızın, İslamiyet'in benimsendiğinin göstergesi olarak "Besmele"nin ve Çerkesliğin göstergesi olan sülale adları ve amblemlerinin işlenmesi, çoklu kimliklerin sadece yaşamsal mekânlarda değil, ölüm alanlarında (deathspaces) da benimsendiğinin göstergesidir. Bu açıdan bakıldığında mezarlıklar, toplumsal kimliğin ritüel mekânı olarak varlığını sürdürmektedir. Böylece kişi yaşamla bağlantısını koparsa bile, kullandığı kimliklerle bağlantısını koparmamakta ve diğer toplum üyeleri tarafından kullandığı kimliklerle tanımlanmaya devam etmektedir. Connerton, kişinin damarlarında dolaşan maddi ve bedensel içerikli olan kanın, "soyağacım”, "aile armam”, "soy çizgim" gibi terimlerle saygınlığa ve tanınırlığa vurgu yapılarak manevileştirildiğine atıfta bulunur (1999, s.134). Gözle görülür nitelikteki kan Böylelikle mezarlıklar, hem manevi hem de maddi mekân olarak işlev görürler. 
Görüşmeciler Çerkes kimliğine ait amblemlerin mezar taşları üzerine işlenmesinin önemli olduğunu belirterek, gerekçe olarak ise oraya gelen Çerkeslerin bu Tamğeları (Damga) gördügüünde aynı sülaleden birilerinin bu bölgede yaşadıklarını görebileceklerini, sürgünle gelen insanların birbirlerini bu yolla bulmaya çalışabileceklerini ifade etmişlerdir. Birçoğu da bu amblemler ya da tanıtıcı bilgiler vasıtasıyla mezarlık ziyareti gerçekleştiren kişilerin burada yatan kişi de Çerkesmiş diyerek en azından bir Fatiha duası okuyabilecekleri düşüncesiyle bu sülale amblemlerinin yapılmasının tercih edildiğini ifade etmişlerdir. Böylece bir ritüel mekân olarak mezarlıkların aynı toplumsal kimliğe sahip bireyleri bir araya getirerek topluluğun aidiyet duygularının perçinlenmesine katkı sağladığı düşünülebilir.

\section{Ölü bedenin göç yolculuğu: Cenaze törenleri}

Topluluğun temel değerleri tarafından şekillendirilen sosyal, kültürel ve dini törenler, insanlar arasındaki birliktelik duygusunu güçlendirir. Diğer topluluklarda olduğu gibi Çerkeslerde de cenaze kaldırma töreni belirli ritüeller çerçevesinde gerçekleştirilmektedir.

Görüşmecinin aktardığı bilgilere göre, geçmiş dönemlerde köylerde, ölüm haberini duyurması için Shako adı verilen ve ölen kişinin akrabası olmayan gençler görevlendirilirdi. $\mathrm{Bu}$ gençler değişik bölgelere giderek ölüm haberini ilgili kişilere iletirdi. Bu arada cenaze başında beklenilir; fakat ağıt yakılmaz ve ölünün başında ağlanılmazdı. Çünkü ölen kişinin ruhunun hala orada olduğu ve tanıdıklarını üzgün görmek istemeyeceğine inanılırdı (Yevtigh, 2017).

Defin işlemleri ölünün yıkanmasıyla başlamaktadır. Cenazenin temiz olmasına özen gösterilmektedir. Defin esnasında kadınlar mezara yaklaştırılmamakta, erkekler bu görevi yerine getirmektedirler. Ölen kişinin yakın akrabası olan erkekler yedi gün boyunca sakallarını tıraş etmemektedirler. Cenaze törenleri esnasında kadın ve erkeklerin toplumsal görevleri ve mekânı kullanım pratikleri arasında farklılıklar gözlenmektedir. Cenaze töreni ve defin işlemleri esnasında erkekler ön planda olurken, kadınlar ev içi alanda yas tutma ve gelen taziyeleri kabul etmekle görevlidir.

Cenaze defnedildikten sonra başsağlığı dilekleri iletilir. Başsağlığı dileklerini yalnızca erkekler kabul etmektedirler. Ölen kişinin akrabası olan erkekler sırayla avluda dizilmekte, mezardan gelen kişiler de onların karşısında yerlerini almaktadırlar. En öndeki sıradan başlayarak kişiler sol ayaklarıyla bir adım öne çıkmakta ve sol ellerini alınlarına götürüp yavaş yavaş indirmektedirler. Bu esnada hiçbir şey söylenmemekte ve kimse sözlü olarak başsağl1ğ1 dileğini iletmemektedir. Bu ritüeli tamamlayan kişiler dönmeden sol ayaklarıyla geri adım atarak yerlerine geçmekte ve tören sonunda tüm topluluk sağ tarafa geçerek dağılmaktadırlar. Zihni’ye göre sağ el sevinç ve mutluluğun ifadesi olduğundan kaldırılması ayıptır (2007, s. 91) Bu ritüel esnasında başsağlığı verecek kişilerin cenaze sahipleri ile karşılıklı olarak dizilmesinin nedeni cenazeye kimlerin katıldığının görülmesidir.

Yukarıda bahsedilen olay kentlerde uygulama alanı bulamasa da Kayseri'nin kimi köylerinde varlığını sürdürdüğü söylenebilir. Kayseri kent merkezinde yaşayan Çerkeslerin ise cenaze törenlerinde günümüz kent koşullarına ayak uydurdukları ve belediyenin sunmuş olduğu taziye çadırlarını kullandıkları gözlenmiştir. Taziye çadırları, sitelerin bahçelerine 
kurulan temsili cenaze evi niteliğindeki mekânlardır. Bu çadır kurulduktan sonra gündelik hayatta sıradan bir site bahçesi olan bu mekân içerisinde yas, üzüntü ve matem alanının inşa edilmiş olduğu düşünülebilir. Genellikle erkekler bu mekânda taziyeleri kabul ederler ve gelen misafirlere burada yemek dağıtımı gerçekleştirilir. Bu açıdan bakıldığında çadırların erkek iktidarında olan bir mekân olduğu yorumu da yapılabilir.

Cenaze törenlerini yas töreni olarak adlandıran Durkheim'a göre tören öncesinde, esnasında ve hatta sonrasında ölen kişinin yakınlarına birtakım yasaklar getirdiği gibi, yapılması gereken edimler de yüklemektedir (2010, s.564). Dolayısıyla Çerkesler arasında da bir yakının ölmesi, uyulması gereken yasakları ve sorumlulukları beraberinde getirir. Görüşmecilerden edinilen bilgilere göre cenaze evinde yedi gün boyunca yemek pişirilmez. Jame Ğavun (ölmüş yakınlar için hamur kızartması pişirip dağıtma) geleneğine bağlı olarak Şelame yani hamur kızartması yedi gün boyunca pişirilir ve taziye için gelenlere ve komşulara dağıtılır. Yemekler komşular ve ikinci dereceden akrabalar tarafindan getirilmektedir. Xabze'ye göre cenaze töreni esnasında tokalaşma, sarılma gibi davranışlar haynape sayılır (Wıka 1, 2016).

Ölüm ile birlikte mekânda da değişiklikler gerçekleşmektedir. Sıradan bir ev bir anda cenaze evine dönüşmektedir. Defin işlemi öncesinde de evin bir odası ölünün bedenine ayrılmaktadır. Burada kişi yeni konumuna hazırlanmak için bekletilmekte ve bu esnada yakınları ölen kişiyi son defa görmek için odaya girmektedirler. Ölüm kişiyi kutsallaştırdığı gibi aynı zamanda da statüsünü değiştirmektedir.

\section{Sonuç}

Mekân ve insan sürekli olarak bir etkileşim içindedir. Bu etkileşim sonucunda ise insan topluluklarının kökleri mekâna dayalı kimlikleri açığa çıkar. Kimi insan toplulukları kendilerini diğer topluluklardan ayırmak için çeşitli taktikler geliştirmişlerdir. Bunlardan biri de yaşarken taşımış oldukları kimlikleri öldükten sonra da yaşatmaktır. Ölüm ile birlikte gelen mekânsal değişimlere rağmen kimlikler, toplumsal bütünleşmeye katkı sağlayacak şekilde mezar taşları üzerinde varlığını sürdürmektedir. Mekânlar zamana ve sahip oldukları niteliklere göre değişik adlandırmalara tabi olurlar. Dolayısıyla nasıl bir insanın kendini tanımlamak için kimlikleri varsa mekânların da kendine özgü kimlikleri mevcuttur. Zira ölü bedeni sınırlandıran mezarlıklar, topluluk üyelerini bir araya getiren, atalar kültünü yansıtan, kültürel belleğin izini sürmeye yardımcı olan ritüel amaçlar için inşa edilmiş mekânlardır.

Mezar taşları diri ve hala hayatta olan bedenler tarafından ölüler için inşa edilir. Kimi zamanda insan hâlâ hayattayken kendi mezarını dizayn edebilmekte annesinin, babasının ya da eşinin yanında öldükten sonraki kendi konumunu henüz hayattayken belirleyebilmektedir. $\mathrm{Bu}$ açıdan bakıldığında ölüm, topluluk üyelerini bedensel olarak ayırsa bile bir gün tekrar birleşme ve bütünleşmenin sağlanacağı inancına göre mekânın biçimlendirilmesini sağlar. Ayrıca mezar taşları vasıtasıyla ölen kişinin konumu mekâna işlenmiş olur, ziyarete gelen kişiler kolaylıkla ölü bedenin yer tayinini yapabilir.

Bir topluluğun varlığının kanıtı olan en önemli gösterge yaşanılan bölgedeki mezar taşlarıdır. Çünkü mezarlıkları yok olan bir toplumun kökleri mekândan silinebilir, sanki orada hiç varlık göstermemişçesine yaşam kanıtları ortadan kaldırılabilir. Özellikle kendi yaşam alan- 
larından zorunlu göç, sürgün gibi çeşitli nedenlerle hareket ettirilmiş, ev sahibi ülkede azınlık konumundaki topluluklar mezarlıklarda varlıklarını belirgin kılmaya daha çok özen gösterme eğilimindedirler. Sonuç olarak da atalar kültüne dayanan ve kökene vurgu yapan kültürel pratikler ölümün mekânında varlığını sürdürmeye devam etmektedir. Böylelikle Kayseri'de yaşayan Çerkes topluluğu da kent merkezindeki görünürlüklerini artırmak için çabalamaktadırlar. Gündelik yaşamda geliştirdikleri yerel dilin kullanımı, kültürel etkinlikler, geleneksel kıyafetlerin kullanımı gibi taktiklerin dışında ölüm ve onun mekânında da Çerkes kimliğini yaşatmak adına pratiklerde bulunmaktadırlar. Bunu yaparken de Kafkasya'dan getirmiş oldukları aile damgaları, Adigey Cumhuriyeti'ne ait bayrak figürleri gibi sembol ve simgeler Kayseri de yaşatılmakta ve mekân içerisinde kültürel kimlik kodlarının taşıyıcılığını üstlenmektedir.

\section{Notlar}

1 Bu makale "Mekân ve Aidiyet İlişkisi Üzerinden Kimlik İnşası: Kayseri Çerkesleri Örneği" başlıklı yüksek lisans tezinden hareketle hazırlanmıştır. Disiplinler arası kavramları bir araya getiren araştırmanın ana konusu, kent merkezinde diasporal Çerkes kimliğinin inşası sürecinde mekân, alan ve bölge içerisine gizlenen aidiyetin köklerini ortaya çıkarmaktır.

2 Annem Hatugoy, babam Kabardey boyuna mensup olduğu için kültürleme sürecimde öğretildiği üzere kendimi Çerkes olarak tanımlıyorum. Bu açıdan bakıldığında doğumumdan bugüne kadar geçen süre aslında bir etnografi deneyimi olarak da nitelendirilebilir.

3 Görüşmelerde katılımcılar, Çerkes toplumunun üyesi bireyler arasından seçilmiştir. Kaynak kişilerden yapılan alıntılar Çerkesce sülale adları kullanılarak gösterilmiştir. Ses kayıt cihazı kullanılmasını uygun görmeyen kişilerle yapılan görüşmelerde notlar tutulmuştur. Ayrıca hatırlatıcı olması açısından katılımcıların kullandığı ve Türkçeye çeviremedikleri kelimeler, görüşme ve gözlem notları tutularak görüşmecilerin kendi dilinde (Adiğabze ile) kaydedilmiş̧tir. Ziyaretler esnasında kimliği açıkça ön plana çıkaran somut nesneler, izin alınarak fotoğraf çekimi ve kamera vasıtasıyla kayıt altına alınmıştır. Gözlem ve görüşme notları ile fotoğraflar, araştırma sonunda bir araya getirilmiş ve elde edilen veriler yorumsamacı bir yaklaşımla analiz edilmiştir.

\section{Kaynaklar}

Akçar M. ve E. Y. Ülker (2014). Sarayönü mezar taşlarına halk edebiyatı açısından bir yaklaşım. (Selçuk Üniversitesi Tarih, Kültür, Sanat, Turizm ve Tarım Açısından Uluslararası Sarayönü Sempozyumu) Bildiriler, Konya: Selçuk Üniversitesi Türkiyat Araştırmaları Enstitüsü, s. 505-529.

Assmann, J. (1997). Kültürel bellek. (çev. A. Tekin) İstanbul: Ayrıntı.

Avagyan, A. (2004). Osmanlı imparatorluğu ve Kemalist Türkiye'nin devlet iktidar sisteminde Çerkesler. (çev. L. Denisenko). İstanbul: Belge.

Bachelard, G. (2013). Mekânın poetikası. (çev. A. Tümertekin). İstanbul: İthaki.

Bağ, Y. (2001). Çerkeslerin dramı, işgal, soykırım, sürgün ve göç. M. Ünal (Ed.) Çerkeslerin Sürgünü içinde (ss.208-248). Ankara: Kafkas Derneği.

Boz, Erdoğan. (2009). Çerkes etnik kimliğinin yeniden inşasında akrabalık. Ankara: Yayımlanmamış Yüksek Lisans Tezi.

Connerton, P. (1999). Toplumlar nasıl anımsar? (çev. A. Şenel). İstanbul: Ayrıntı.

Çağırkan, B. (2016). Göç, hibrit kimlik ve aidiyet: yeni toplumlar, yeni kimlikler, Insan ve Toplum Bilimleri Araştırmaları Dergisi 5 (8), 2613-2623. 
Durkheim, E. (2010). Dinsel yaşamın ilk biçimleri. (çev. Ö. Ozankaya). İstanbul: Cem.

Kantemur, Z. (2018). Mekan ve aidiyet ilişkisi üzerinden kimlik inşası: Kayseri Çerkesleri örneği. Kayseri: Yayımlanmamış Yüksek Lisans Tezi.

Karasar, N. (1995). Bilimsel araştırma yöntemi. Ankara: 3A Araştırma Eğitim Danışmanlık.

Kartarı, A. (2006). Farklılıklarla Yaşamak/Kültürlerarası İletişim. Ankara: Ürün.

Kümbetoğlu, B. (2005). Sosyolojide ve Antropolojide niteliksel yöntem ve araştırma. İstanbul: Bağlam. Lefebvre, H. (2014). Mekânın üretimi. (çev. I. Ergüden). İstanbul: Sel.

Marshall, G. (1999). Sosyoloji sözlüğü. Ankara: Bilim ve Sanat.

Nahya Z.N. ve Harmanşah R. (2016). Etnografik hikâyeler Türkiye'de alan araştırması deneyimleri. İstanbul: Metis.

Örnek S. V. (1977). Türk halkbilimi. Ankara: Türkiye İş Bankas1 Kültür.

Ponty, M. (2002). Phenomenology of perception. London: Routledge.

Sağır, A. (2013). Ölüm, kültür ve kimlik: Iğdır ölü bayramı ve Meksika ölü günü örneği. Milli Folklor Dergisi 25 (98), 125-137.

Saltık, T. (2000). Tarihsel mücadele sürecinde Adiğeler, Abhazlar, Alanlar (Osetinler), Çeçenler. İstanbul: Berfin.

Savage, M. (2005). Globalization\&Belonging. London: Sage.

Stavrides, S. (2016). Kentsel heteretopya özgürleşme mekânı olarak eşikler kentine doğru. İstanbul: Sel.

Turner, V. (2013). Eşikte olma hali ve cemaat. Kültür ve toplum güncel tartışmalar (ed.J. C. Alexander, S. Seidman). İstanbul: Boğaziçi Üniversitesi.

Zihni, Z. (2007). Çerkesya'da terbiye ve sosyal yaşayış. Ankara: Kafdav. 